Article

\title{
Unprecedented Insights on Chemical and Biological Significance of Euphorbia cactus Growing in Saudi Arabia
}

\author{
Gadah A. Al-Hamoud ${ }^{1, *, \dagger}{ }^{1}$, Omer I. Fantoukh ${ }^{1, *},+\oplus$, Musarat Amina ${ }^{1}$, Fahd A. Nasr ${ }^{1} \oplus$, Nawal M. Al Musayeib ${ }^{1}$,

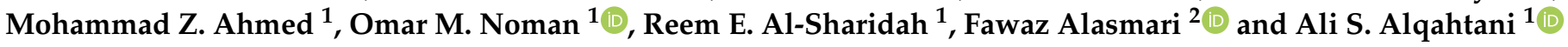 \\ 1 Department of Pharmacognosy, College of Pharmacy, King Saud University, Riyadh 11451, Saudi Arabia; \\ mamina@ksu.edu.sa (M.A.); fnasr@ksu.edu.sa (F.A.N.); nalmusayeib@ksu.edu.sa (N.M.A.M.); \\ mahmed4@ksu.edu.sa (M.Z.A.); onoman@ksu.edu.sa (O.M.N.); 438201922@student.ksu.edu.sa (R.E.A.-S.); \\ alalqahtani@ksu.edu.sa (A.S.A.) \\ 2 Department of Pharmacology and Toxicology, College of Pharmacy, King Saud University, Riyadh 11451, \\ Saudi Arabia; ffalasmari@ksu.edu.sa \\ * Correspondence: galhamoud@ksu.edu.sa (G.A.A.-H.); ofantoukh@ksu.edu.sa (O.I.F.) \\ + These authors contributed equally to this work.
}

\section{check for}

updates

Citation: Al-Hamoud, G.A.;

Fantoukh, O.I.; Amina, M.; Nasr, F.A.;

Musayeib, N.M.A.; Ahmed, M.Z.;

Noman, O.M.; Al-Sharidah, R.E.;

Alasmari, F.; Alqahtani, A.S.

Unprecedented Insights on Chemical

and Biological Significance of

Euphorbia cactus Growing in Saudi

Arabia. Plants 2022, 11, 681. https://

doi.org/10.3390/plants11050681

Academic Editor: Petko Denev

Received: 7 February 2022

Accepted: 28 February 2022

Published: 2 March 2022

Publisher's Note: MDPI stays neutral with regard to jurisdictional claims in published maps and institutional affiliations.

Copyright: (c) 2022 by the authors. Licensee MDPI, Basel, Switzerland. This article is an open access article distributed under the terms and conditions of the Creative Commons Attribution (CC BY) license (https:// creativecommons.org/licenses/by/ $4.0 /)$.

\begin{abstract}
Euphorbia cactus Ehrenb ex Boiss. is a plant species reported from central Africa and the southern Arabian Peninsula, belonging to the family of Euphorbiaceae. The plant has ethnobotanical values and is well-known for its milky latex, which has been turned into medicine to treat various ailments. To the best of our knowledge, there have been no literature reports available on phytochemical constituents and antiproliferative mechanism of E. cactus. In the current study, the phytochemical investigation of E. cactus methanolic extract (ECME) resulted in the isolation and characterization of four secondary metabolites, which are reported for the first time from this plant species. In addition, the results of 1,1-diphenyl-2-picrylhydrazyl (DPPH•) and ferrous ion chelating (FIC) assays expressed maximum antioxidant activity by ECME and the isolated phytochemicals. Furthermore, ECME exerted a promising antiproliferative effect against different cancer cell lines, and the A549 lung cancer cells were the most sensitive with an $\mathrm{IC}_{50}$ value of $20 \mu \mathrm{g} / \mathrm{mL}$. The antiproliferative action of ECME in A549 cells was associated with cell accumulation in the G2/M phase and an increase in early and late apoptosis. In addition, RT-PCR and western blot analysis revealed that ECME decreased the anti-apoptotic (Bcl-2) expression, while the expression of pro-apoptotic (Bax) and caspase- 3 were increased. This study provides the first insight into the phytochemical constituents and the antiproliferative mechanism of ECME, implying that it could be exploited as a promising natural source for developing new cancer therapies. Further preclinical research is warranted to support the current results.
\end{abstract}

Keywords: Euphorbia cactus; phytochemicals; antioxidant; cytotoxicity

\section{Introduction}

Euphorbia is the third largest genus of flowering plants in the Euphorbiaceae family, with almost 2000 species distributed in tropical and subtropical climate zones. The rich morphological variability and near-cosmopolitan distribution of Euphorbia have caught attention worldwide since ancient times [1]. Euphorbia species are readily distinguishable by their specialized inflorescences and milky latex [1-3]. The plants of this genus are commonly used for ornamental and household purposes [4]. The genus is well known for the chemical diversity of its isoprenoid components [5]. Some plants of this genus are of great importance, and they have been used as traditional folk medicine to treat skin disease, venomous bites, abdominal pain, abdominal distention, trichiasis, as wart removers, and to treat paralysis [6].

Chemically, diterpenoids with various core frameworks such as jatrophanes, ingenanes, lathyranes, myrsinols, and tiglianes are the main components found in Euphorbia. 
Other reported chemical constituents were sesquiterpenoids, cerebrosides, flavonoids, phloracetophenones, steroids, and glycerols [5]. Various pharmacological properties have been reported for the genus Euphorbia including antioxidant, antibacterial, antifungal, antiviral, anti-inflammatory, and cytotoxic effects $[7,8]$. The extract of latex of these plants has shown co-carcinogenic activity due to the presence of diterpene esters (tigliane and ingenane), and it has been banned from commercial uses $[9,10]$. However, many secondary metabolites found in the latex extract have anticarcinogenic activities [11,12].

Euphorbia cactus Ehrenb ex Boiss. (Family; Euphorbiaceae) is a perennial succulent leafless spiny shrub with 3-4 angled dark green branches mottled with radiating yellow streaks. It is widely distributed in central Africa and the southern Arabian Peninsula and reaches up to $3 \mathrm{~m}$ high. Fruit capsules are dull red 3-angular with $8-9 \times 15-16 \mathrm{~mm}$ in size [13]. The extract of E. cactus latex showed antileishmanial activity [14], whereas the crude methanolic extract of the whole plant has been reported to exhibit antioxidant, antimicrobial, and anticancer activities [15]. Considering the pharmacological activity of E. cactus extracts, different parts of the plants need further investigation. To the best of our knowledge, the plant species has not been extensively explored for its chemical and pharmacological potential. In our continued quest to explore the flora of Saudi Arabia, the current study aimed to investigate the phytochemical, antiproliferative, apoptotic and antioxidant properties of methanolic extract of aerial parts of E. cactus (ECME).

\section{Results and Discussion}

\subsection{Preliminary Phytochemical Screening}

The phytochemical study of ECME revealed a broad diversity of phytochemicals. The major phytochemical constituents included phenols, diterpenes, flavonoids, sesquiterpenoids, terpenoids, anthocyanins, tannins, steroids, anthraquinones, carbohydrates, cerebrosides, phloracetophenones, glycerols, and alkaloids were present in the methanol extract (Table 1).

Table 1. Qualitative screening of phytoconstituents present in the methanolic extract of aerial parts of E. cactus (ECME).

\begin{tabular}{cc}
\hline Phytochemicals & ECME \\
\hline Phenols & +++ \\
Flavonoids & ++ \\
Diterpenes & +++ \\
Sesquiterpenoids & ++ \\
Terpenoids & ++ \\
Anthocyanins & ++ \\
Tannins & ++ \\
Steroids & ++ \\
Cerebrosides & + \\
Anthraquinones & ++ \\
Phloracetophenones & + \\
Glycerols & + \\
Alkaloids & + \\
Carbohydrates & ++ \\
Saponins & - \\
\hline+++ (Pesent in excess), ++ (Present significantly), + (present in traces), - (absent)
\end{tabular}

\subsection{Isolation of Chemical Constituents}

Phytochemical investigation of ECME aerial parts resulted in the isolation and characterization of four secondary metabolites (Figure 1). Their chemical structures were established using NMR, IR, and MS, and by comparison of obtained data with the available literature. Specifically, the obtained compounds were one triterpenoid and three flavonoids, which have been reported for the first time from this plant species and in agreement with the chemotaxonomic profile of the genus Euphorbia. Glutinol (1) is a rare pentacyclic triter- 
penoid, and it was isolated previously from the whole plant of Euphorbia segetalis [16] and leaves of Euphorbia ammak growing in Saudi Arabia [17]. Catechin (2) is widely distributed in the plants and was previously reported from Euphorbia denticulate [18] and Euphorbia dracunculoides [19]. Kaempferol-3-O- $\alpha$-L-rhamnopyranoside (3) and quercetin-3-O- $\alpha$-Lrhamnpyranoside (4) are well-known active flavonoids and were previously isolated from Euphorbia davidii and Euphorbia sanctae-catharinae [20,21].

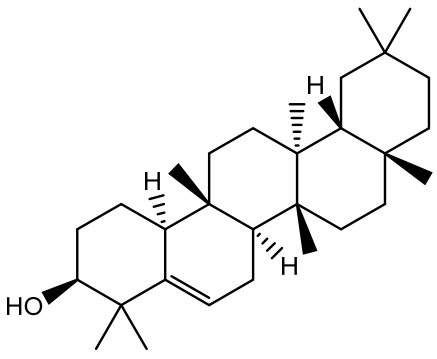

Glutinol (1)<smiles>C[C@H]1OC(Oc2c(-c3ccc(O)cc3)oc3cc(O)cc(O)c3c2=O)[C@H](O)[C@@H](O)[C@@H]1O</smiles>

Kaempferol-3-O- $\alpha$-L-rhamnopyranoside (3)<smiles>Oc1cc(O)c2c(c1)O[C@H](c1ccc(O)c(O)c1)[C@H](O)C2</smiles>

Catechin (2)<smiles>C[C@@H]1OC(Oc2c(-c3ccc(O)c(O)c3)oc3cc(O)cc(O)c3c2=O)[C@H](O)[C@H](O)[C@H]1O</smiles>

Quercetin-3-O- $\alpha$-L-rhamnopyranoside (4)

Figure 1. Chemical structures of secondary metabolites isolated from the methanolic extract of aerial parts of E. cactus (ECME).

\subsection{Antioxidant Activity}

A free radical is a molecular species containing an unpaired electron and is engaged in bacterial, fungal, and parasitic infections, inflammation, atherosclerosis, lung damage, reperfusion injury, aging, neoplastic, and cardiovascular and autoimmune disorders [22,23]. The results of our study demonstrated that ECME exerted free radical scavenging activity in vitro models including $\mathrm{DPPH}^{\bullet}$ and FIC assays.

\subsubsection{Free Radical Scavenging Activity $\left(\mathrm{DPPH}^{\bullet}\right)$}

$\mathrm{DPPH}^{\bullet}$ free radicals are widely used for investigating the preliminary radical scavenging effect of the plant extract [24]. Scavenging of $\mathrm{DPPH}^{\bullet}$ radical is associated with lipid peroxidation inhibition [25]. DPPH ${ }^{\bullet}$ is a substance used to test antioxidant activity [26]. Antioxidants either shift a hydrogen atom or an electron to the DPPH${ }^{\bullet}$ and neutralize its free radical feature [27]. DPPH ${ }^{\bullet}$ test is based on the ability of stable DPPH ${ }^{\bullet}$ free radical to decolorize in the presence of antioxidants and is considered a reliable procedure for determining the action of radical scavenging [28]. Several studies in the literature have addressed the free radical scavenging activity of different Euphorbia species [29-32]. In the current study, the highest inhibition percentage was observed with ECME (89.75), followed by compound 3 (69.35) and compound 4 (62.21) at $200 \mu \mathrm{g} \mathrm{mL}^{-1}$ (Table 2). Furthermore, it was observed that ECME displayed more pronounced scavenging activity, in contrast to isolated compounds as well as BHT standard (Table 2). This result could be attributed 
to the synergistic effect of isolated compounds 1-4 or other minor components present in the extract.

Table 2. Free radical scavenging $\left(\mathrm{DPPH}^{\bullet}\right)$ and ferrous ion chelating (FIC) activity of ECME and isolated phytochemicals.

\begin{tabular}{ccccc}
\hline \multirow{2}{*}{ Sample } & \multicolumn{2}{c}{$\mathbf{D P P H}^{\bullet}$ Radical Scavenging } & \multicolumn{2}{c}{ Ferrous Ion Chelating Activity } \\
\cline { 2 - 5 } & $\begin{array}{c}\text { Concentration } \\
\left(\mu \mathbf{g ~ m L}^{-\mathbf{1})}\right.\end{array}$ & $\begin{array}{c}\text { Inhibition } \\
\mathbf{( \% )}\end{array}$ & $\begin{array}{c}\text { Concentration } \\
\left(\boldsymbol{\mu} \mathbf{g ~ m L}^{-\mathbf{1})}\right.\end{array}$ & $\begin{array}{c}\text { Inhibition } \\
\mathbf{( \% )}\end{array}$ \\
\hline ECME & 200 & $89.75 \pm 0.35$ & 3000 & $36.12 \pm 0.45$ \\
Compound 1 & 200 & $52.34 \pm 0.26$ & 3000 & $41.23 \pm 0.26$ \\
Compound 2 & 200 & $49.12 \pm 0.34$ & 3000 & $53.14 \pm 0.22$ \\
Compound 3 & 200 & $69.35 \pm 0.24$ & 3000 & $56.24 \pm 0.36$ \\
Compound 4 & 200 & $62.21 \pm 0.14$ & 3000 & $62.45 \pm 0.42$ \\
BHT & 200 & $41.16 \pm 0.36$ & - & - \\
EDTA & - & - & 3000 & $95.58 \pm 0.45$ \\
\hline
\end{tabular}

BHT and ETDA were used as reference standards. Values were measured in triplicates and represented as mean \pm SD.

\subsubsection{Ferrous Ion Chelating Assay (FIC)}

Iron is an essential metal for life and plays a crucial role in the transport of oxygen, respiration and activity of various enzymes. However, it is a highly reactive metal and catalyzes oxidative changes in proteins, lipids and other components of the cell [33]. The metal chelating capacity of ECME was determined by the ferrous ion ferrozine- $\mathrm{Fe}^{2+}$ complex formation. Ferrous ions unite with ferrozine, resulting in a red-colored complex that shows absorbance at $562 \mathrm{~nm}$ [34]. Chelating agents forming $\sigma$ bonds with the metal are considered effective secondary antioxidants as they have the ability to decrease the redox potential and stabilize the metal ion in its oxidized form [34]. The iron-binding ability of ECME and isolated compounds 1-4 were measured as a percentage of inhibition, and compound 4 showed the highest potential $(62.45 \%)$, followed by compound $3(56.24 \%)$ and compound $2(53.14 \%)$ at $3000 \mu \mathrm{g} \mathrm{mL}^{-1}$ concentrations (Table 2). However, ECME and compound 1 exhibited moderate effects at similar concentrations, which was not comparable to that of the EDTA reference standard.

\subsection{Antiproliferative and Apoptotic Activity of ECME}

MTT assay was employed to assess the growth inhibitory effect of ECME on A549, LoVo, MCF-7 cancer cells and HUVEC normal cells to study its antiproliferative effect. We found that ECME reduced the viability of all tested cells in a concentration-dependent manner (Figure 2). The $\mathrm{IC}_{50}$ values of ECME on the cancer and normal cells were $20.1 \pm 0.5$ (A549), $53.2 \pm 0.4$ (LoVo), $58.80 \pm 1.83$ (MCF-7), and $65.26 \pm 2.80 \mu \mathrm{g} / \mathrm{mL}$ (HUVEC) (Table 3).

In fact, the cytotoxic activity for several species of Euphorbia genus, including $E$. hirta [32], E. formosana [35], E. tirucalli [36], and E. helioscopia [37] against various cancer cells have been reported. However, limited studies regarding the cytotoxic activity of $E$. cactus species have been determined. A previous study analyzed the cytotoxic activity of E. cactus that grew in Yemen against human bladder carcinoma cell line [38]. Another study found that $E$. cactus methanolic extract exhibited a potent cytotoxic effect against MCF-7 (breast), HepG2 (liver) and PC-3 (prostate) cancer cells with $\mathrm{IC}_{50}$ values ranging from $17-27 \mu \mathrm{g} / \mathrm{mL}$ [15]. Here, the $\mathrm{IC}_{50}$ values reported were slightly different from the previous study, and this variance could be attributed to differences in the plant parts as well as type of cell lines used in both studies. 


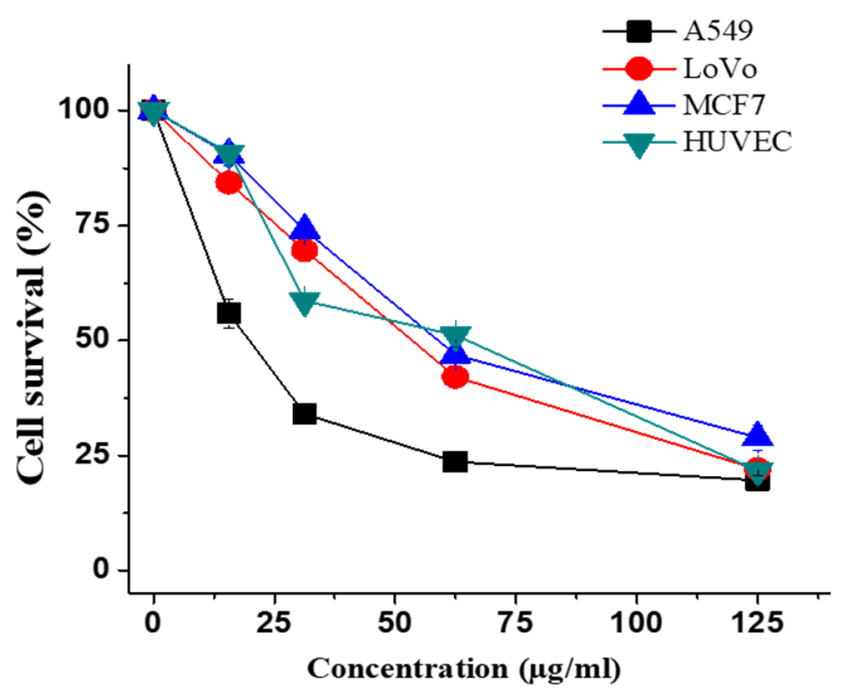

Figure 2. Effect of ECME on the viability of various cancer cells. Cells were treated with increasing concentrations for $48 \mathrm{~h}$, and cell survival was estimated by an MTT assay. The percentage of cells' survival was determined as compared with the untreated cells.

Table 3. IC $_{50}$ of ECME against cancer (A549, LoVo, and MCF-7) and normal (HUVEC) cell lines as measured by MTT assay. Values were measured in triplicates and represented as mean $\pm \mathrm{SD}$ and presented as $\mu \mathrm{g} / \mathrm{mL}$.

\begin{tabular}{ccccc}
\hline \multicolumn{5}{c}{ Cell lines and IC $_{50}(\mu \mathrm{g} / \mathrm{mL})$} \\
\hline A549 & LoVo & MCF-7 & HUVEC \\
\hline ECME & $20.1 \pm 0.5$ & $53.2 \pm 0.4$ & $58.80 \pm 1.83$ & $65.26 \pm 2.80$ \\
Doxorubicin & $1.20 \pm 0.02$ & $1.30 \pm 0.05$ & $1.40 \pm 0.02$ & $4.1 \pm 0.2$ \\
\hline
\end{tabular}

Furthermore, compounds 1-4 were tested for their antiproliferative activity against the most responsive cells (A549 cells). The results showed that compounds $\mathbf{2}-\mathbf{4}$ did not display any cytotoxic activity while glutinol (1) exhibited a weak cytotoxic activity $\left(\mathrm{IC}_{50}>100 \mu \mathrm{g} / \mathrm{mL}\right)$, which were in line with previous studies [21,39]. Thus, a synergistic effect for these compounds may explain the observed antiproliferative activity of the methanol extract. In addition, the observed activity could be attributed to some minor components existed in the extract.

Overall, our results indicated that ECME had a promising growth inhibitory effect on A549 lung cancer cells. Hence, A549 cells were selected for further investigation. Next, flow cytometry was employed to evaluate cell cycle progression to understand the antiproliferative mechanism exerted by ECME. To this end, A549 cells were incubated for $48 \mathrm{~h}$ with ECME at the half and $\mathrm{IC}_{50}$ concentrations $(10$ and $20 \mu \mathrm{g} / \mathrm{mL})$ and stained with propidium iodide (PI). As shown in (Figure 3), ECME increased cell number at G2/M phase to $27.5 \pm 0.2$ and $36.1 \pm 0.2 \%$ after $48 \mathrm{~h}$ of treatment with 10 and $20 \mu \mathrm{g} / \mathrm{mL}$ respectively compared to untreated cells $(16.8 \pm 1.4 \%)$. This increase was accompanied by decreased cell numbers at the $S$ phase, and this result clearly indicates that ECME caused G2/M cell cycle arrest. In fact, the G2/M phase is required for cell entry into the $\mathrm{M}$ phase, and it is also linked to tumor cell resistance [40]. Hence, ECME can be a promising source of agents for cell growth inhibition. 


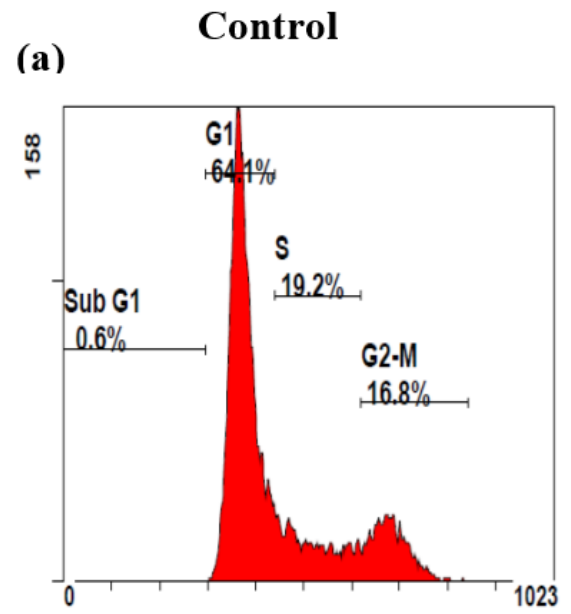

PI Intensity
ECME $(10 \mu \mathrm{g} / \mathrm{mL})$

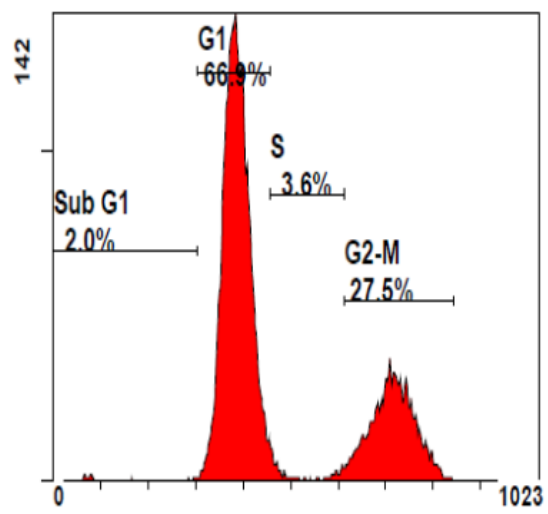

PI Intensity
ECME $(20 \mu \mathrm{g} / \mathrm{mL})$

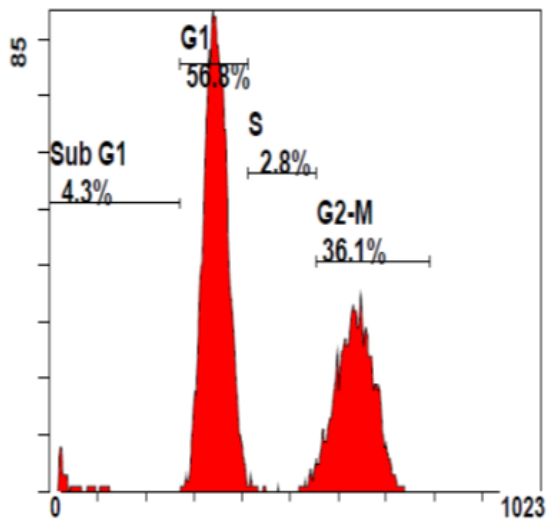

PI Intensity

(b)

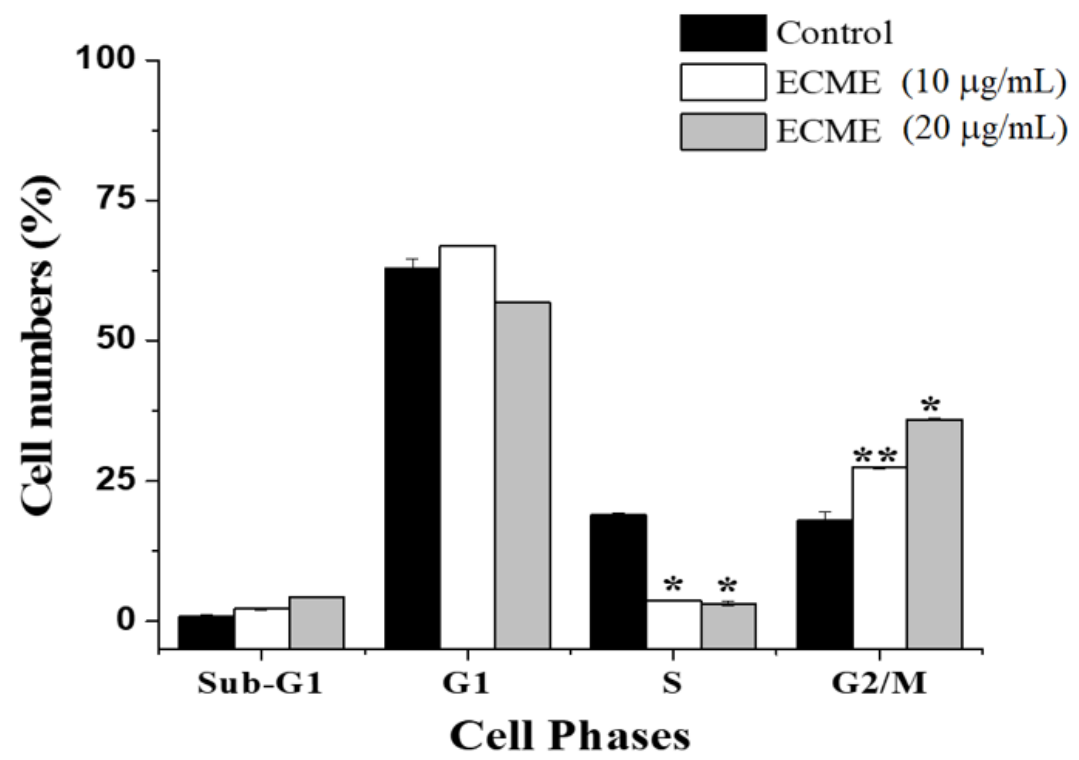

Figure 3. ECME induces G2/M phase cell cycle arrest in A549 cells. (a) The histogram shows the distribution of cell phases after treatment with corresponding $\mathrm{IC}_{50}$ and its half concentrations (20 and $10 \mu \mathrm{g} / \mathrm{mL}$ ) of ECME. (b) The values indicate the percentage of cells in the indicated phases of the cell cycle. Significant differences from the control are indicated by $p<0.05 ;{ }^{* *} p<0.01$.

Excessive cell proliferation and apoptosis evasion are also among the key characteristics of tumor cells that influence cancer onset and progression [41]. As a result, reducing tumor cell proliferation and inducing apoptosis are considered substantial options for tumor treatment. Therefore, a quantitative assessment of apoptosis was performed by Annexin-FITC/PI staining to investigate whether ECME has mediated cellular apoptosis. As illustrated in (Figure 4), the populations of cells undergoing early and late stages were increased in a concentration-dependent manner after exposure to ECME. The early apoptotic rates in the A549 cells were increased to $13.6 \pm 1.1$ and $22.8 \pm 0.5 \%$ while late apoptotic cells were raised to $6.7 \pm 0.3$ and $16.2 \pm 0.8 \%$ following treatment ECME at 10 and $20 \mu \mathrm{g} / \mathrm{mL}$ for $48 \mathrm{~h}$, respectively (Figure 4 ). 
(a)

Control

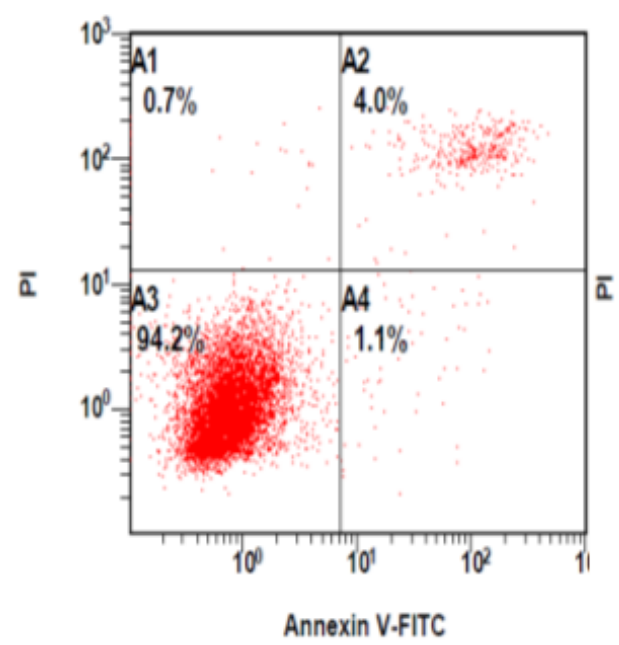

ECME $(10 \mu \mathrm{g} / \mathrm{mL})$

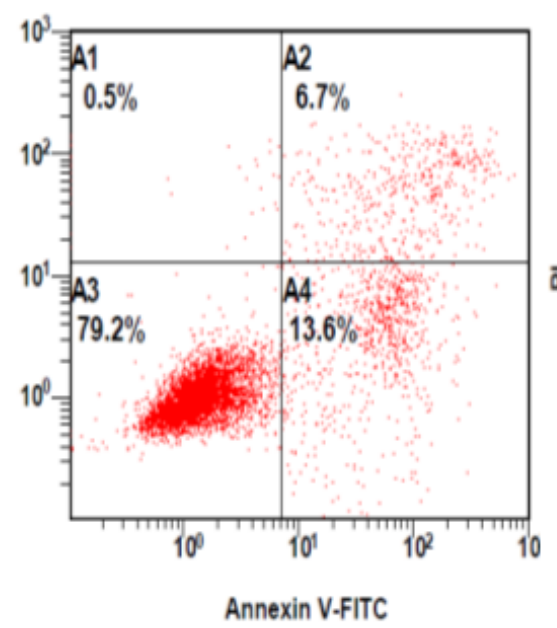

ECME (20 $\mu \mathrm{g} / \mathrm{mL})$

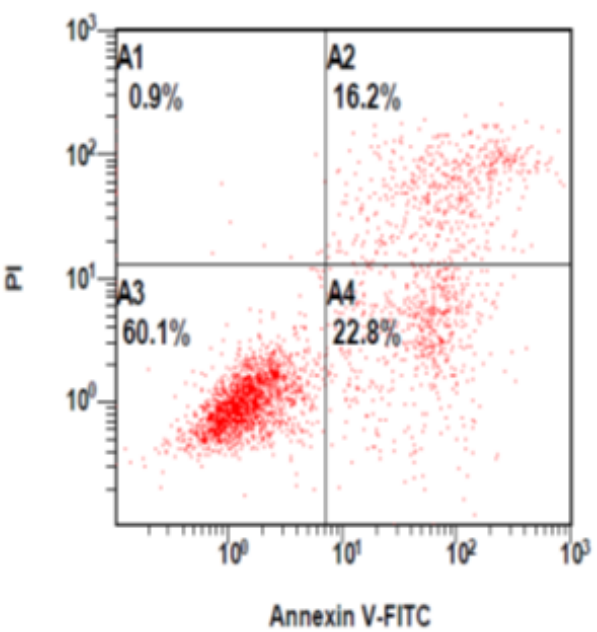

(b)

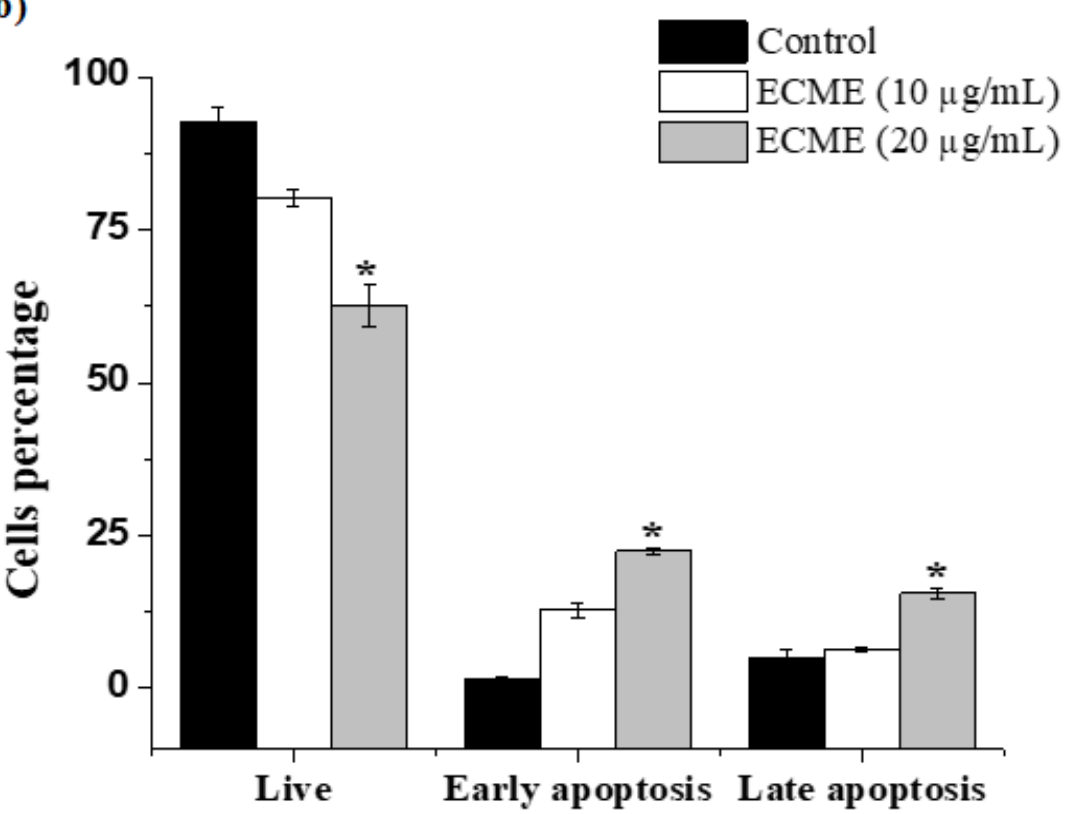

Figure 4. Apoptosis induction in A549 by ECME as detected by Annexin V/PI assay. (a) Apoptosis histogram of control cells, and cells treated with 10 and $20 \mu \mathrm{g} / \mathrm{mL}$. A1: Cells labeled with PI only (necrosis), A2: cells labeled with annexin V and PI (late apoptosis), A3: Viable cells and A4: early apoptotic cells (Annexin V+/PI-) -. (b) Apoptosis percentage data from three experiments (mean $\pm \mathrm{SD}, * p<0.05$ vs. control group).

It is well known that the anti-apoptotic Bcl-2 and pro-apoptotic Bax proteins play a critical role in the initiation of apoptotic cell death [42]. Other enzymes, mainly caspases, are also among fundamental mediators of apoptosis cell death. Among them, caspase-3, which is widely expressed and known to play a typical role in apoptosis events [43]. Thus, the effects of ECME on cell apoptosis markers, including Bax, Bcl-2 and caspase- 3 were determined at gene and protein levels. Following treatment with ECME, our findings revealed that overexpression of Bax and downregulation of Bcl-2 happened simultaneously in A549 cells. A significant increase of caspase 3 was also observed in ECME-treated cells (Figure 5). Additionally, Bax, Bcl-2 and caspase-3 were detected at protein levels in ECME treated cells using western blot. As indicated in (Figure 6), A549 cells exposed 
to 10 or $20 \mu \mathrm{g} / \mathrm{mL}$ of ECMC display significant $(p<0.01)$ expression levels of Bax and caspase 3 proteins compared to the control. Furthermore, ECME reduced Bcl-2 protein expression with a statistical difference as shown in Figure 6, as compared to untreated cells, which clearly demonstrates the enrollment of these proteins in ECME-induced apoptosis in A549 cells. Since the antiproliferative activity of E. cactus species has not been previously investigated at cellular and molecular levels, our study of this species is considered unique to date. On the other hand, the cell cycle arrest and apoptosis induction for several species of Euphorbia genus have been documented [7]. Our findings agree with a previously published report which mentioned that E. hirta methanol extract has induced apoptotic cell death and G2/M phases arrest in MCF-7 breast cancer cells [44]. In line with our study, the treatment of various cell lines with hexane extracts from three species of Euphorbia genus (E. microciadia, E. osyridea and E. heteradenia) resulted in similar apoptotic effects including early and late apoptosis cells populations increment, modulating the ratio of Bax and Bcl-2 expression as well as caspase 3 activation [45].

(a)

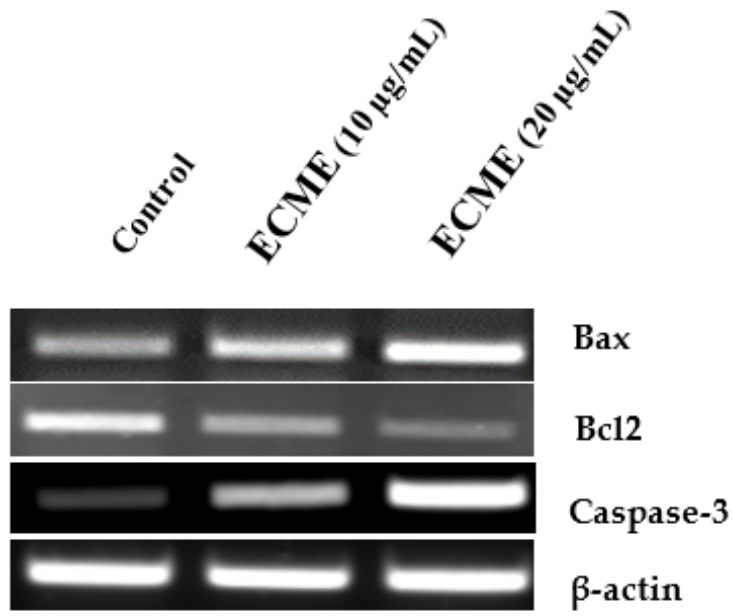

(b)

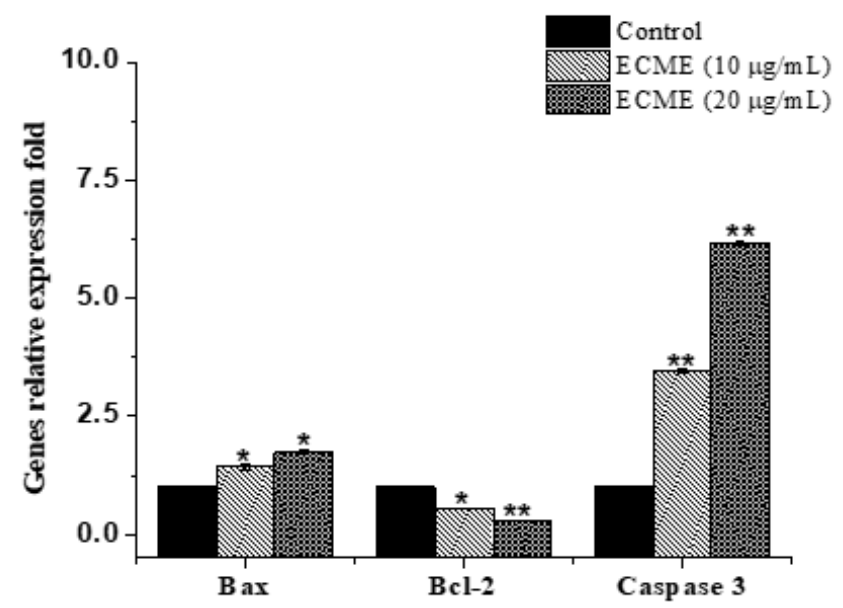

Figure 5. Effects of ECME on the expression levels of Bax, Bcl-2 and caspase 3 genes determined via RT-PCR analysis. A549 cells were exposed to ECME at two effective concentrations of ECME for $48 \mathrm{~h}$, while the negative control was treated with DMSO (0.01\%). (a) The expression of apoptosis-related genes, including Bax, Bcl-2 and caspase- 3 were detected by RT-PCR and $\beta$-actin was employed as internal a reference. $(\mathbf{b})$ The quantitative level is display in histograms and the average value $(n=3)$, for the control was set at one. ${ }^{*} p<0.05,{ }^{* *} p<0.01$ vs. the control group. 
(a)

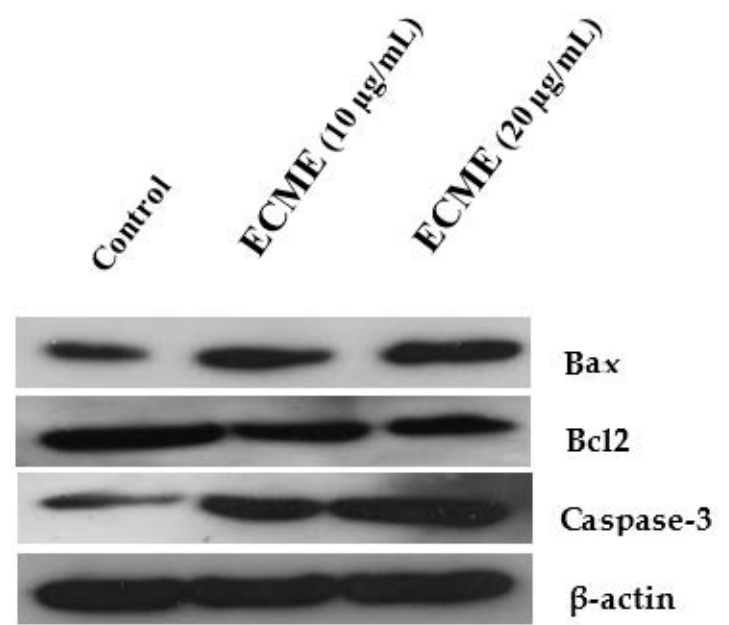

(b)

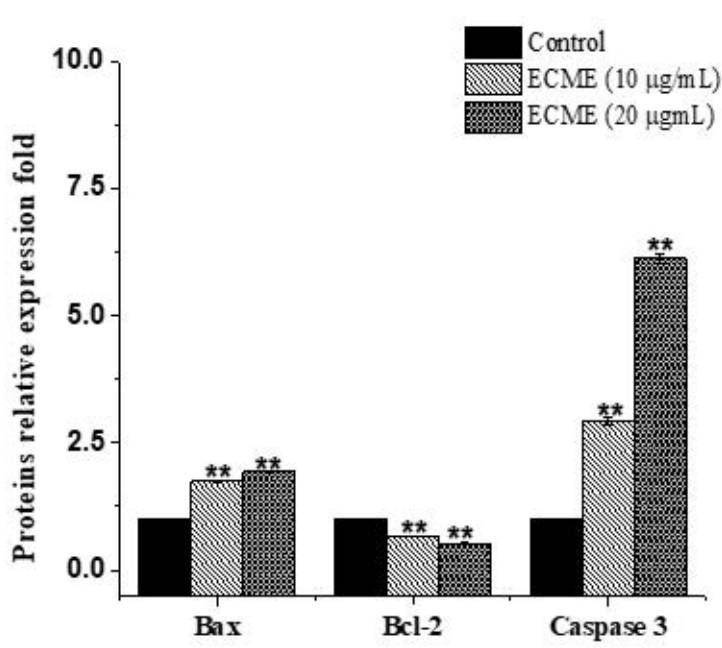

Figure 6. Effect of ECME on protein levels of proapoptotic and antiapoptotic proteins. A549 cells were treated with vehicle $(0.01 \%$ DMSO) or at two effective concentrations of ECME for $48 \mathrm{~h}$. (a) Immunoblot analysis displaying expression levels of Bax, Bcl-2 and Caspase-3. (b) Graph depicting the relative intensity of studied proteins versus ECME concentration. The data is the average of three experiments with standard deviation. ${ }^{* *} p<0.01$ vs. the control group.

\section{Materials and Methods}

\subsection{Plant Material}

The aerial parts of E. cactus were collected from Fayfa mountains $\left(17^{\circ} 15^{\prime} 01.2^{\prime \prime} \mathrm{N}\right.$, $43^{\circ} 06^{\prime} 40.6^{\prime \prime} \mathrm{E}$ ) in the southern region of Saudi Arabia in November 2019 and were taxonomically identified by Dr. Ali Mohammed Alzahrani from the Biology Department, Al-Baha University, Saudi Arabia. A voucher specimen (EC-14984) was deposited in the herbarium of the Pharmacognosy Department.

\subsection{Preparation of Extract}

The freshly collected aerial parts of E. cactus were thoroughly washed with tap water and rinsed in distilled water before they were cut into small pieces and dried under shade at ambient temperature for 7 days. The dried plant material was finely powdered using a domestic blender and preserved in airtight plastic bags prior to use. The dry powder of the plant sample $(300 \mathrm{~g})$ was extracted with methanol solvent $(1000 \mathrm{~mL})$ in a Soxhlet apparatus for $72 \mathrm{~h}$ at room temperature. The extraction process was repeated three times under similar conditions. All the methanolic extracts were combined, centrifuged, filtered through Whatman No.1 filter paper, and the filtrates were concentrated on a rotary evaporator under reduced pressure at $50{ }^{\circ} \mathrm{C}$ to remove the organic solvent. A viscous dark green gummy residue $(15.23 \mathrm{~g})$ was obtained and kept at $4{ }^{\circ} \mathrm{C}$ before use.

\subsection{Preliminary Phytochemical Screening}

The phytochemical screening of ECME was following previously methods with slight modification [46]. A standard solution was prepared by dissolving $100 \mathrm{mg}$ of extract in $10 \mathrm{~mL}$ of methanol. The prepared solution was then evaluated for the existence of different phytochemical components, including phenols, flavonoids, diterpenes, sesquiterpenoids, terpenoids, anthocyanins, tannins, steroids, cerebrosides, anthraquinones, phloracetophenones, glycerols, alkaloids, carbohydrates, and saponins.

\subsection{Isolation of Chemical Constituents}

For the purpose of determining the biological activity and active ingredients, the concentrated methanol extract $(10.2 \mathrm{~g})$ of E. cactus was diluted with distilled water $(100 \mathrm{~mL})$, and the resulting suspension solution was partitioned successively with chloroform $(3 \times 300 \mathrm{~mL})$, 
ethyl acetate $(3 \times 300 \mathrm{~mL})$, and $n$-butanol $(3 \times 300 \mathrm{~mL})$ in the glass separating funnel to obtain $5.7 \mathrm{~g}$ of chloroform, $2.2 \mathrm{~g}$ of ethyl acetate, $1.4 \mathrm{~g}$ of $n$-butanol, and $0.9 \mathrm{~g}$ of aqueous fractions, respectively. The chloroform and ethyl acetate fraction showed a similar TLC pattern with numerous phytoconstituents, were combined and taken up for column chromatography over silica gel (230-400 mesh). The elution was performed with a mixture of chloroform and methanol of increasing polarity to obtain six subfractions EC1-EC6. The subfraction EC1 $(213 \mathrm{mg})$ was packed in a glass column $(50 \times 2 \mathrm{~cm})$ over silica gel $(40 \mathrm{~g}$, 60-120 mesh) using as eluent gradient n-hexane: ethyl acetate to yield compound $\mathbf{1}(8.4 \mathrm{mg})$ as amorphous white solid after recrystallization in $\mathrm{MeOH}$. The subfraction EC2 (325 mg) was chromatographed over $\mathrm{SiO}_{2}$ gel column under the same conditions as subfraction EC1 and provided compound $2(32.3 \mathrm{mg})$ as a white amorphous powder. The combined subfractions EC3 and EC4 (425 mg) was loaded over silica gel (80 g, 60-120 mesh) in a glass column $(50 \times 2 \mathrm{~cm})$ using a solvent mixture of $\mathrm{CHCl}_{3}$ and $\mathrm{MeOH}$ with a gradual increase in polarity yielded compound 3 (20.3 $\mathrm{mg})$. Subfraction EC6 (546 $\mathrm{mg}$ ) was packed over LH-20 Sephadex column using $\mathrm{MeOH}$ as eluent to provide a major fraction, EC-6A (251 mg). The purification of EC-6A (251 mg) was conducted on RP18 $(60 \mathrm{~g} \times 2 \mathrm{~cm})$ column and eluted with gradient $\mathrm{MeOH}: \mathrm{H}_{2} \mathrm{O}$ to afford compound $4(6.8 \mathrm{mg})$ amorphous yellow solid after crystallization in $\mathrm{MeOH}$.

Spectral Analysis of Isolated Compounds

Glutinol (1): White powder; [ $\alpha$ ]D: +53.85 (c 0.85, $\mathrm{CHCl}_{3}$ ); MS/ESI: $m / z$ 426, calculated for $\mathrm{C}_{30} \mathrm{H}_{50} \mathrm{O}, 449$ [M+Na]+, IR (KBr) vmax: 2934, 2865, 1643, $3453 \mathrm{~cm}-1$; UV (MeOH) $\lambda \max$ (log $\varepsilon$ ): 212 (4.36); $1 \mathrm{H}$ NMR data (500 MHz, CDCl3) $\delta \mathrm{H}$ (ppm): 5.62 (1H, m, H-6), 3.45 (1H, br s, H-3), 1.21 (3H, s, H-28), 1.15 (3H, s, H-24), 1.12 (3H, s, H-27), 1.08 (3H, s, H-23), 1.03 (3H, s, H-26), 0.99 (3H, s, H-29), 0.97 (3H, s, H-30), 0.83 (3H, s, H-25); 13C NMR (125 $\mathrm{MHz}, \mathrm{CDCl} 3) \delta \mathrm{c}(\mathrm{ppm}): 141.69$ (C-5), 122.16 (C-6), 76.53 (C-3), 49.76 (C-10), 47.50 (C-8), 43.13 (C-18), 40.91 (C-4), 39.37 (C-13), 39.04 (C-22), 37.91 (C-14), 36.10 (C-16), 35.15 (C-19), 33.92 (C-9), 34.69 (C-11), 34.61 (C-29), 33.19 (C-21), 32.50 (C-30), 32.15 (C-15), 32.13 (C-28), 30.44 (C-12), 30.17 (C-17), 29.04 (C-24), 28.34 (C-20), 27.90 (C-2), 25.55 (C-23), 23.72 (C-7), 19.71 (C-26), 18.52 (C-27), 18.30 (C-1), 16.30 (C-25). NMR data were comparable to those reported in the literature was identified as Glutinol [47].

Catechin (2): Amorphous yellow powder; MS/ESI: $m / z 290$, calculated for $\mathrm{C}_{15} \mathrm{H}_{14} \mathrm{O}_{6}, 313$ [M+Na]+; IR (KBr) vmax: 3400, 1622, 1523, 1460, 1240, 1130, 1060, $830 \mathrm{~cm} \mathrm{-1;} \mathrm{UV} \mathrm{(MeOH)}$ $\lambda \max (\log \varepsilon): 220$ (4.25), 290 (2.65) nm; 1H NMR data (500 MHz, CD3OD) $\delta H ~(p p m): 5.90$ (1H, s, H-8), 5.82 (1H, s, H-6), 4.53 (1H, d, H-2), 3.94 (1H, ddd, H-3), 2.82 (4H, dd, H- $\beta), 2.47$ $(1 \mathrm{H}, \mathrm{dd}, \mathrm{H}-4 \alpha), 6.81\left(1 \mathrm{H}, \mathrm{d}, \mathrm{H}-6^{\prime}\right), 6.73\left(1 \mathrm{H}, \mathrm{d}, \mathrm{H}-5^{\prime}\right), 6.69\left(1 \mathrm{H}, \mathrm{d}, \mathrm{H}-2^{\prime}\right)$; $13 \mathrm{C} \mathrm{NMR}(125 \mathrm{MHz}$, CD3OD) $\delta \mathrm{H}(\mathrm{ppm}): 156.52$ (C-7), 156.26 (C-5), 155.59 (C-9), 144.90 (C-4'), 144.90 (C-3'), $130.87\left(\mathrm{C}-1^{\prime}\right), 118.70\left(\mathrm{C}-6^{\prime}\right), 114.72\left(\mathrm{C}-5^{\prime}\right), 113.91\left(\mathrm{C}-2^{\prime}\right), 99.45$ (C-10), 94.92 (C-6), $94.13(\mathrm{C}-8)$, 81.53 (C-2), 67.49 (C-3), 27.21 (C-4). NMR data were comparable to those reported in the literature was identified as Catechin [48].

Kaempferol-3-O- $\alpha$-L-rhamnopyranoside (3): Amorphous yellow powder MS/ESI: m/z 432 calculated for $\mathrm{C}_{21} \mathrm{H}_{20} \mathrm{O}_{10}, 455$ [M+Na]+; IR (KBr) vmax: 3550, 2924, 1650, 1610, 1590, 1450 cm-1; UV (MeOH) $\lambda \max (\log \varepsilon): 348$ (4.06), 267 (4.04) nm; $1 \mathrm{H}$ NMR data $(500 \mathrm{MHz}$, CD3OD) $\delta \mathrm{H}$ (ppm): 7.74 (2H, d, H-2' , H-6'), 6.91 (2H, d, H-3', H-5'), 6.35 (1H, d, H-8), $6.18(1 \mathrm{H}, \mathrm{d}, \mathrm{H}-6), 5.35\left(1 \mathrm{H}, \mathrm{d}, \mathrm{H}-1^{\prime \prime}\right), 4.19\left(1 \mathrm{H}, \mathrm{dd}, \mathrm{H}-2^{\prime \prime}\right), 3.68\left(1 \mathrm{H}, \mathrm{dd}, \mathrm{H}-3^{\prime \prime}\right), 3.48(1 \mathrm{H}, \mathrm{m}$,

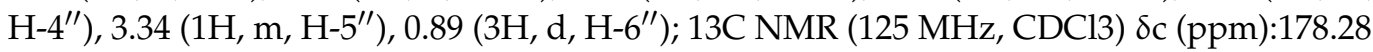
(C-4), 164.80 (C-7), 161.91 (C-5), 160.29 (C-4'), 157.95 (C-2), 157.26 (C-9), 134.86 (C-3), $130.57\left(\mathrm{C}-2^{\prime}, 6^{\prime}\right), 121.30\left(\mathrm{C}-1^{\prime}\right), 115.20\left(\mathrm{C}-3^{\prime}, 5^{\prime}\right), 104.52(\mathrm{C}-10), 102.19\left(\mathrm{C}-1^{\prime \prime}\right), 98.57(\mathrm{C}-6)$, $93.46(\mathrm{C}-8), 71.83\left(\mathrm{C}-4^{\prime \prime}\right), 70.77\left(\mathrm{C}-3^{\prime \prime}\right), 70.71\left(\mathrm{C}-5^{\prime \prime}\right), 70.58\left(\mathrm{C}-2^{\prime \prime}\right), 16.31\left(\mathrm{C}-6^{\prime \prime}\right)$. NMR data were comparable to those reported in the literature was identified as Kaempferol-3-O- $\alpha$-Lrhamnopyranoside [49].

Quercetin-3-O- $\alpha$-L-rhamnopyranoside (4): Amorphous yellow powder; MS/ESI: $m / z 448$ calculated for $\mathrm{C}_{21} \mathrm{H}_{20} \mathrm{O}_{11}, 471$ [M+Na]+;IR (KBr) vmax: 3190, 2921, 1652, 1356, 1197, 808 $\mathrm{cm}-1$; UV (MeOH) $\lambda \max (\log \varepsilon): 257$ (4.25), 356 (4.10) nm; 1H NMR data (500 MHz, 
CD3OD) $\delta \mathrm{H}(\mathrm{ppm}): 7.30\left(1 \mathrm{H}, \mathrm{d}, \mathrm{H}-2^{\prime}\right), 7.28\left(1 \mathrm{H}, \mathrm{dd}, \mathrm{H}-6^{\prime}\right), 6.88\left(1 \mathrm{H}, \mathrm{d}, \mathrm{H}-5^{\prime}\right), 6.34(1 \mathrm{H}, \mathrm{d}$, $\mathrm{H}-8), 6.17$ (1H, d, H-6), $5.32\left(1 \mathrm{H}, \mathrm{d}, \mathrm{H}-1^{\prime \prime}\right), 4.19\left(1 \mathrm{H}, \mathrm{dd}, \mathrm{H}-2^{\prime \prime}\right), 3.72\left(1 \mathrm{H}, \mathrm{dd}, \mathrm{H}-3^{\prime \prime}\right), 3.39$ $\left(1 \mathrm{H}, \mathrm{dd}, \mathrm{H}-5^{\prime \prime}\right), 3.31\left(1 \mathrm{H}, \mathrm{dd}, \mathrm{H}-4^{\prime \prime}\right), 0.91\left(3 \mathrm{H}, \mathrm{d}, \mathrm{H}-6^{\prime \prime}\right) ; 13 \mathrm{C}$ NMR (125 MHz, CDCl3) $\delta \mathrm{c}$ (ppm):178.31 (C-4), 164.80 (C-7), 161.89 (C-5), 157.96 (C-9), 157.22 (C-2), 148.50 (C-4'), 145.11 $\left(\mathrm{C}-3^{\prime}\right), 134.89(\mathrm{C}-3), 121.63\left(\mathrm{C}-1^{\prime}\right), 121.52\left(\mathrm{C}-6^{\prime}\right), 115.58\left(\mathrm{C}-5^{\prime}\right), 115.03\left(\mathrm{C}-2^{\prime}\right), 104.49(\mathrm{C}-10)$, $102.22\left(\mathrm{C}-1^{\prime \prime}\right), 98.55(\mathrm{C}-6), 93.42(\mathrm{C}-8), 71.91\left(\mathrm{C}-4^{\prime \prime}\right), 70.77\left(\mathrm{C}-2^{\prime \prime}\right), 70.70\left(\mathrm{C}-3^{\prime \prime}\right), 70.57\left(\mathrm{C}-5^{\prime \prime}\right)$, $16.32\left(\mathrm{C}-6^{\prime \prime}\right)$. NMR data were comparable to those reported in the literature was identified as Quercetin-3-O- $\alpha$-L-rhamnopyranoside [50].

\subsection{Antioxidant Activity}

The free radical scavenging activity of ECME was assessed by using two different in vitro assays, including $\mathrm{DPPH}^{\bullet}$ and FIC assays.

\subsubsection{DPPH• Assay}

The DPPH${ }^{\bullet}$ radical-scavenging activity of ECME was evaluated by following the Kirby and Schmidt method [51] with slight modifications. Briefly, $500 \mu \mathrm{L}$ of ECME at different concentrations $(100,200,300,400$, and $500 \mu \mathrm{g} / \mathrm{mL})$ was mixed with $375 \mu \mathrm{L}$ of methanol $(99 \%)$, followed by the addition of $125 \mu \mathrm{L}$ of a DPPH ${ }^{\bullet}$ solution (prepared by $0.2 \mathrm{mM}$ $\mathrm{DPPH}^{\bullet}$ in methanol) as a source of free radicals. The reaction mixture was incubated under dark conditions for $30 \mathrm{~min}$ at room temperature. After incubation, scavenging capacity was determined spectrophotometrically (UV-VIS T70 Spectrometer, PG Instruments Ltd., Wibtoft, UK) by observing the decrease in absorbance at $517 \mathrm{~nm}^{\text {. DPPH }}{ }^{\bullet}$ radical displays an absorption band at $517 \mathrm{~nm}$, which completely disappears by an antiradical compound reduction. Butylated hydroxytoluene $(\mathrm{BHT})$ was applied as appositive control. Experiments were performed in triplicates and the inhibition percentage was determined by comparison of the absorbance values of control with the test sample using the following equation:

$$
\text { Inhibition percentage }=\frac{A b s_{\text {Control }}-A b s_{\text {test sample }}}{A b s_{\text {control }}} \times 100
$$

\subsubsection{Ferrous Ion Chelating Assay (FIC)}

The chelating of ferrous ions by ECME was determined by obeying [52] procedure with slight modifications. Briefly, different concentrations (1000, 2000, 3000, 4000, and $5000 \mu \mathrm{g} / \mathrm{mL}$ ) of methanol extract were mixed with $100 \mu \mathrm{L}$ of $2 \mathrm{mM}$ ferrous sulphate solution and $300 \mu \mathrm{L}$ of $5 \mathrm{mM}$ ferrozine. The mixed solution was incubated for $10 \mathrm{~min}$ at room temperature. After incubation, the absorbance of the solution was recorded at $562 \mathrm{~nm}$. All the tests were carried out in triplicates and the standard used was ethylene diamine tetra acetate (EDTA). The inhibition percentage was determined using the Equation (1).

\subsection{Cytotoxicity Assay}

The cytotoxic activity of ECME against A549 (lung), LoVo (colon), MCF-7 (breast) cancer cells and normal HUVEC cell line was determined by MTT assay as previously described [53]. Cells were seeded in 96 well plates with a count of $5 \times 10^{4}$ cells per well. After $24 \mathrm{~h}$ of incubation, cells were treated with the extract at different concentrations (125, $62.5,31.25$ and $15.625 \mu \mathrm{g} / \mathrm{mL}$ ), doxorubicin as a positive control or dimethyl sulfoxide $(0.01 \% \mathrm{DMSO})$ as a vehicle negative control and incubated for $48 \mathrm{~h}$. After incubation, MTT $(5 \mathrm{mg} / \mathrm{mL}, 10 \mu \mathrm{L}$ ) was added per well and further incubated for $4 \mathrm{~h}$. Thereafter, the medium was removed, and the purple formazan crystals were dissolved in isopropanol containing $1 \mathrm{~N} \mathrm{HCl}$. All samples were treated in triplicate and the absorbance was measured at $570 \mathrm{~nm}$ with a multi-plate reader (Bio-Tek, Elx-800, Winooski, VT, USA). Cell viability was calculated as $(\%)=($ O.D of the treated sample $) /($ O.D of the untreated sample $) \times 100$. The $\mathrm{IC}_{50}$ (concentration of the extract that inhibits $50 \%$ of cell growth) was generated from the concentration-response curve. 


\subsection{Cell Cycle Analysis}

Cell cycle assay was carried out according to the protocol reported by [54]. In brief, A549 cells were plated in 6-well culture plates. After $24 \mathrm{~h}$ of incubation, cells were exposed to corresponding $\mathrm{IC}_{50}$ and its half concentrations $(20$ and $10 \mu \mathrm{g} / \mathrm{mL})$ of ECME or DMSO as a control. At the endpoint of treatment $(48 \mathrm{~h})$, the cells were detached, harvested by centrifugation, washed twice with ice-cold PBS and fixed in ice-cold absolute ethanol for $4 \mathrm{~h}$ at $4{ }^{\circ} \mathrm{C}$. Thereafter, the cell pellet was resuspended and incubated with a $0.5 \mathrm{~mL}$ propidium iodide (PI) staining solution (50 $\mu \mathrm{g} / \mathrm{mL}$ PI and $100 \mu \mathrm{g} / \mathrm{mL}$ RNase A) for $30 \mathrm{~min}$ in the dark. The cell cycle stages were analyzed using a FACS flow cytometer (Cytomics FC 500; Beckman Coulter, Brea, CA, USA). CXP software v.3.0 was used for data collection and analysis.

\subsection{Annexin V-FITC/PI Apoptosis Detection}

The protocol was followed according to the manufacturer's instructions (Biolegend, USA). In brief, at $48 \mathrm{~h}$ after treatment, floating cells and adherent cells were collected, and the pelleted cells were washed with PBS. Thereafter, the pelleted cells were resuspended in Annexin binding buffer $(100 \mu \mathrm{L})$ and transferred to cytometer tubes. Cells staining was performed by the addition of $5 \mu \mathrm{L}$ from both dyes $(5 \mu \mathrm{L}$ of FITC Annexin V and $5 \mu \mathrm{L}$ propidium iodide) and incubated (10-15 $\mathrm{min}$ ) in the dark. This was followed by the addition of $0.4 \mathrm{~mL}$ of incubation buffer, and the cells were analyzed immediately on FACS flow cytometer (Cytomics FC 500; Beckman Coulter, Brea, CA, USA).

\subsection{RNA Extraction and RT-PCR}

A549 cells were cultured in 6-well plates at $2.5 \times 10^{5}$ cells per $2 \mathrm{~mL}$ for each well. On the next day, the media were changed, and the cells were either treated with the vehicle $(0.1 \%$ DMSO) or plant extract (dissolved in DMSO) at 10 and $20 \mu \mathrm{g} / \mathrm{mL}$ concentrations. Total RNA from the vehicle and treated cells were prepared using Trizol reagent as described by the manufacturer (Invitrogen, Thermo Fisher Scientific, lnc., Waltham, MA, USA). An equal amount of RNA ( $1 \mu \mathrm{g})$ was used to synthesize cDNA using a cDNA synthesis kit (Invitrogen, Thermo Fisher Scientific, lnc., Waltham, MA, USA) according to the manufacturer's guideline and was used as a template for RT-PCR. A semiquantitative PCR was carried out to determine the expression level of caspase-3, Bax, and $\mathrm{Bcl}-2$, while $\beta$-Actin was used as an internal control. The final volume $(20 \mu \mathrm{L})$ of the RT-PCR mixture, which consist of $2 \mu \mathrm{L}$ of cDNA, $4 \mu \mathrm{L}$ of 5X FIRE pol Master mix (Solis Bio Dyne, Tartu, Estonia), and 10 pmol of each complementary primer specific for their respective genes were used. The sequences of specific primers were as follows: Bax 5'-TTTGCTTCAGGGTTTCATCC-3' ${ }^{\prime}$, and R: $5^{\prime}$-ATCCTCTGCAGCTCCATGTT-3'; Bcl-2 F: $5^{\prime}$-TGATGCCTTCTGTGAAGCAC-3' and R: $5^{\prime}$-ACAGGCGGAGCTTCTTGTAA- $3^{\prime}$; caspase3: F: $5^{\prime}$-TGGAATTGATGCGTGATGTT- $3^{\prime}$ and R: $5^{\prime}$-GGCAGGCCTGAATAATGAAA- $3^{\prime}$ and $\beta$-actin: F: $5^{\prime}$-CATCGTGATGGACTCTGGTG- $3^{\prime}$ and R: $5^{\prime}$-TTTGATGTCACGCACGATTT$3^{\prime}$. The sample was initially denatured at $95^{\circ} \mathrm{C}$ for $5 \mathrm{~min}$ and amplified using 32 cycles of denaturation at $95^{\circ} \mathrm{C}$ for $30 \mathrm{~s}$, annealing at $55^{\circ} \mathrm{C}$ for $60 \mathrm{~s}$, and elongation at $72{ }^{\circ} \mathrm{C}$ for $60 \mathrm{~s}$. followed by final elongation at $72{ }^{\circ} \mathrm{C}$ for $5 \mathrm{~min}$. The final amplification products of $20 \mu \mathrm{L}$ were run on $1.2 \%$ of agarose gel ethidium that was bromide-stained, and the gel picture was taken on LICOR gel doc.

\subsection{Western Blot}

A549 cells were treated either with the vehicle ( $0.1 \%$ DMSO) or plant extract (dissolved in DMSO) at 10 and $20 \mu \mathrm{g} / \mathrm{mL}$ concentrations for $24 \mathrm{~h}$. After $24 \mathrm{~h}$ of treatment, the cells were washed twice with 1x PBS, and then cells were lysed by resuspending in $150 \mu \mathrm{L}$ of lysis buffer (20 mM Tris (pH 7.5), $150 \mathrm{mM} \mathrm{NaCl}, 1 \mathrm{mM}$ sodium EDTA, $1 \mathrm{mM}$ ethylene glycolbis ( $\beta$-aminoethyl ether)- $N, N, N^{\prime}, N^{\prime}$-tetraacetic acid, $1 \%$ Triton $X-100,1 \mu \mathrm{g} / \mathrm{mL}$ leupeptin, and $100 \mu \mathrm{M}$ phenylmethylsulfonyl fluoride). The cell lysates were centrifuged, and total protein content was determined using Bio-Rad reagent. Proteins were transferred onto the 
nitrocellulose membrane following the electrophoresis by the wet transfer method using Bio-Rad electrotransfer apparatus (Bio-Rad Laboratories, CA, USA). The membranes were then blocked with 5\% BSA (in Tris buffer saline containing $0.1 \%$ Tween 20 ) by incubating it for $2 \mathrm{~h}$ at room temperature, The membranes were washed $3 \mathrm{X}$ with TBST and then incubated with the desired primary antibodies on the rocker at $4{ }^{\circ} \mathrm{C}$ for overnight. On the next day, membranes were washed 3X with TBST and then incubated with horseradish peroxidase (HRP) conjugated secondary antibodies (at room temperature for $1 \mathrm{~h}$ ). The membranes were washed 3X, and the ECL (Thermo Scientific) solution was used to detect the signal by exposing it to an X-ray film.

\subsection{Statistical Analysis}

OriginPro 8.5 software was used to conduct statistical analysis, display data graphically and $\mathrm{IC}_{50}$ values calculation. The statistical differences between control and treated groups were analyzed using Student's paired t-test. Data was presented as mean \pm SD of three experimental observations. Statistical significance was defined as ${ }^{* *} p<0.01$, $* p<0.05$.

\section{Conclusions}

Phytochemical investigation of ECME resulted in one triterpenoid along with three flavonoids which have been reported from E. cactus for the first time. Furthermore, ECME was found to display an antiproliferative activity towards various cancer cells, especially the A549 lung cancer cells, possibly via induction of apoptosis and G2/M cell cycle phase arrest. Apoptosis mediating by ECME was potentially through modulating of Bax, Bcl2 , and caspase- 3 proteins. These findings are the primary insights to demonstrate the antiproliferative mechanism of E. cactus, suggesting that it might be a promising natural source for developing novel therapeutics against cancer. However, further preclinical studies should be conducted to support the current results.

Author Contributions: Conceptualization, G.A.A.-H. and O.I.F.; methodology, G.A.A.-H., O.I.F., M.A., F.A.N., M.Z.A., O.M.N. and R.E.A.-S.; software, F.A.N.; validation, F.A.N. and F.A.; formal analysis, F.A.N. and F.A.; investigation, G.A.A.-H., O.I.F., M.A., F.A.N. and F.A.; resources, G.A.A.-H., O.I.F., N.M.A.M. and A.S.A.; data curation, G.A.A.-H., O.I.F., M.A., F.A.N., M.Z.A., O.M.N. and R.E.A.-S.; writing—original draft preparation, G.A.A.-H., O.I.F., M.A. and F.A.N.; writing-review and editing, N.M.A.M., F.A. and A.S.A.; visualization, F.A.N. and M.Z.A.; supervision, G.A.A.-H., O.I.F., N.M.A.M. and A.S.A.; project administration, G.A.A.-H. and O.I.F.; funding acquisition, N.M.A.M. and A.S.A. All authors have read and agreed to the published version of the manuscript.

Funding: This research was funded by Researchers Supporting Project number (RSP-2021/294), King Saud University, Riyadh, Saudi Arabia.

Institutional Review Board Statement: Not applicable.

Informed Consent Statement: Not applicable.

Data Availability Statement: All data generated or analyzed in the current study are included in this article.

Acknowledgments: Authors are thankful to the Researchers Supporting Project number (RSP2021/294), King Saud University, Riyadh, Saudi Arabia.

Conflicts of Interest: The authors clarified that no conflict of interest in this study. 


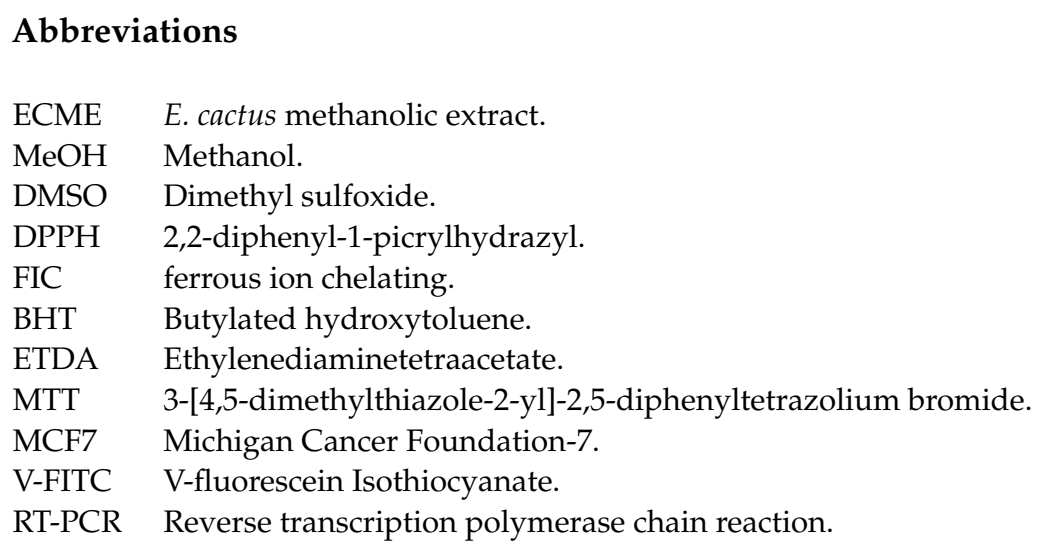

\section{References}

1. Horn, J.W.; Xi, Z.; Riina, R.; Peirson, J.A.; Yang, Y.; Dorsey, B.L.; Berry, P.E.; Davis, C.C.; Wurdack, K.J. Evolutionary bursts in Euphorbia (Euphorbiaceae) are linked with photosynthetic pathway. Evolution 2014, 68, 3485-3504. [CrossRef] [PubMed]

2. Prenner, G.; Rudall, P.J. Comparative ontogeny of the cyathium in Euphorbia (Euphorbiaceae) and its allies: Exploring the organ-flower-inflorescence boundary. Am. J. Bot. 2007, 94, 1612-1629. [CrossRef] [PubMed]

3. Govaerts, R.l.; Frodin, D.G.; Radcliffe-Smith, A. World Checklist and Bibliography of Euphorbiaceae (with Pandaceae); Royal Botanic Gardens, Kew: Richmond, UK, 2000; Volume 2.

4. Rizk, A.-F.M. The chemical constituents and economic plants of the Euphorbiaceae. Bot. J. Linn. Soc. 1987, 94, 293-326. [CrossRef]

5. $\quad$ Ernst, M.; Nothias, L.F.; van der Hooft, J.J.J.; Silva, R.R.; Saslis-Lagoudakis, C.H.; Grace, O.M.; Martinez-Swatson, K.; Hassemer G.; Funez, L.A.; Simonsen, H.T.; et al. Assessing Specialized Metabolite Diversity in the Cosmopolitan Plant Genus Euphorbia L. Front. Plant Sci. 2019, 10, 846. [CrossRef] [PubMed]

6. Ernst, M.; Saslis-Lagoudakis, C.H.; Grace, O.M.; Nilsson, N.; Simonsen, H.T.; Horn, J.W.; Ronsted, N. Evolutionary prediction of medicinal properties in the genus Euphorbia L. Sci. Rep. 2016, 6, 30531. [CrossRef]

7. Kemboi, D.; Peter, X.; Langat, M.; Tembu, J. A Review of the Ethnomedicinal Uses, Biological Activities, and Triterpenoids of Euphorbia Species. Molecules 2020, 25, 4019. [CrossRef]

8. Salehi, B.; Iriti, M.; Vitalini, S.; Antolak, H.; Pawlikowska, E.; Kregiel, D.; Sharifi-Rad, J.; Oyeleye, S.I.; Ademiluyi, A.O.; Czopek, K.; et al. Euphorbia-Derived Natural Products with Potential for Use in Health Maintenance. Biomolecules 2019, 9, 337. [CrossRef]

9. Aya, T.; Kinoshita, T.; Imai, S.; Koizumi, S.; Mizuno, F.; Osato, T.; Satoh, C.; Oikawa, T.; Kuzumaki, N.; Ohigashi, H.; et al Chromosome translocation and c-MYC activation by Epstein-Barr virus and Euphorbia tirucalli in B lymphocytes. Lancet 1991, 337, 1190. [CrossRef]

10. Fürstenberger, G.; Hecker, E. On the active principles of the Euphorbiaceae, XII. Highly unsaturated irritant diterpene esters from Euphorbia tirucalli originating from Madagascar. J. Nat. Prod. 1986, 49, 386-397. [CrossRef]

11. Prakash, E.; Gupta, D.K. Cytotoxic Activities of Extracts of Medicinal Plants of Euphorbiacae Family Studied on Seven Human Cancer Cell lines. Univers. J. Plant Sci. 2013, 1, 113-117. [CrossRef]

12. Sharma, V.; Pracheta. Anti-carcinogenic potential of Euphorbia neriifolia leaves and isolated flavonoid against N-nitrosodiethylamineinduced renal carcinogenesis in mice. Indian J. Biochem. Biophys. 2013, 50, 521-528. [PubMed]

13. Fayed, A.A.; Al-Zahrani, D.A. Three New Spiny Euphorbia (Euphorbiaceae) Species from Western Saudi Arabia. Edinb. J. Bot. 2007, 64, 117-129. [CrossRef]

14. Al- Hajj, M.M.A.; Al-Shamahy, H.A.; Alkhatib, B.Y.; Moharram, B.A. In Vitro Anti-Leishmanial Activity against Cutaneous Leishmania Parasites and Preliminary Phytochemical Analysis of Four Yemeni Medicinal Plants. Univers. J. Pharm. Res. 2018, 3, 48-54. [CrossRef]

15. Al-Faifi, Z.I. In vitro Anticancer, Antioxidant and Antimicrobial Activities of Crude Methanolic Extract of Euphorbia cactus Ehrenb Plant. Int. J. Pharmacol. 2019, 15, 907-915. [CrossRef]

16. Madureira, A.M.; Ascenso, J.R.; Valdeira, L.; Duarte, A.; Frade, J.P.; Freitas, G.; Ferreira, M.J. Evaluation of the antiviral and antimicrobial activities of triterpenes isolated from Euphorbia segetalis. Nat. Prod. Res. 2003, 17, 375-380. [CrossRef] [PubMed]

17. Abdel-Sattar, E.; Abou-Hussein, D.; Petereit, F. Chemical Constituents from the Leaves of Euphorbia ammak Growing in Saudi Arabia. Pharmacogn. Res. 2015, 7, 14-17. [CrossRef]

18. Zengin, G.; Uysal, A.; Aktumsek, A.; Mocan, A.; Mollica, A.; Locatelli, M.; Custodio, L.; Neng, N.R.; Nogueira, J.M.F.; Aumeeruddy-Elalfi, Z.; et al. Euphorbia denticulata Lam.: A promising source of phyto-pharmaceuticals for the development of novel functional formulations. Biomed. Pharm. 2017, 87, 27-36. [CrossRef]

19. Majid, M.; Khan, M.R.; Shah, N.A.; Ul Haq, I.; Farooq, M.A.; Ullah, S.; Sharif, A.; Zahra, Z.; Younis, T.; Sajid, M. Studies on phytochemical, antioxidant, anti-inflammatory and analgesic activities of Euphorbia dracunculoides. BMC Complementary Altern. Med. 2015, 15, 349. [CrossRef]

20. Rédei, D.; Kúsz, N.; Szabó, M.; Pinke, G.; Zupkó, I.; Hohmann, J. First phytochemical investigation of secondary metabolites of Euphorbia davidii Subils. and antiproliferative activity of its extracts. Acta Biol. Hung. 2015, 66, 464-467. [CrossRef] 
21. Hegazy, M.F.; Hamed, A.R.; Ibrahim, M.A.A.; Talat, Z.; Reda, E.H.; Abdel-Azim, N.S.; Hammouda, F.M.; Nakamura, S.; Matsuda, H.; Haggag, E.G.; et al. Euphosantianane A(-)D: Antiproliferative Premyrsinane Diterpenoids from the Endemic Egyptian Plant Euphorbia Sanctae-Catharinae. Molecules 2018, 23, 2221. [CrossRef]

22. Al-Hamoud, G.A.; Saud Orfali, R.; Perveen, S.; Mizuno, K.; Takeda, Y.; Nehira, T.; Masuda, K.; Sugimoto, S.; Yamano, Y.; Otsuka, H.; et al. Lasianosides A-E: New Iridoid Glucosides from the Leaves of Lasianthus verticillatus (Lour.) Merr. and Their Antioxidant Activity. Molecules 2019, 24, 3995. [CrossRef]

23. Diplock, A.T. Chapter 4-Antioxidants and free radical scavengers. In New Comprehensive Biochemistry; Rice-Evans, C.A., Burdon, R.H., Eds.; Elsevier: Amsterdam, The Netherlands, 1994; Volume 28, pp. 113-130.

24. Al-Yousef, H.M.; Fantoukh, O.I.; El-Sayed, M.A.; Amina, M.; Adel, R.; Hassan, W.H.B.; Abdelaziz, S. Metabolic profiling and biological activities of the aerial parts of Micromeria imbricata Forssk. growing in Saudi Arabia. Saudi J. Biol. Sci. 2021, 28, 5609-5616. [CrossRef] [PubMed]

25. Varzaru, I.; Untea, A.E.; Saracila, M. In Vitro Antioxidant Properties of Berry Leaves and Their Inhibitory Effect on Lipid Peroxidation of Thigh Meat from Broiler Chickens. Eur. J. Lipid Sci. Technol. 2020, 122, 1900384. [CrossRef]

26. Budi, H.S.; Pebriani, I. The Difference of Temperature and Storage Time on the Antioxidant Activity of Curcuma Ethanol Extract (Curcuma zanthorrhiza) using the DPPH. Syst. Rev. Pharm. 2020, 11, 324-331. [CrossRef]

27. Lopez-Martinez, L.M.; Santacruz-Ortega, H.; Navarro, R.E.; Sotelo-Mundo, R.R.; Gonzalez-Aguilar, G.A. A (1)H NMR Investigation of the Interaction between Phenolic Acids Found in Mango (Manguifera indica cv Ataulfo) and Papaya (Carica papaya cv Maradol) and 1,1-diphenyl-2-picrylhydrazyl (DPPH) Free Radicals. PLoS ONE 2015, 10, e0140242. [CrossRef]

28. Bursal, E.; Aras, A.; Kilic, O.; Buldurun, K. Chemical constituent and radical scavenging antioxidant activity of Anthemis kotschyana Boiss. Nat. Prod. Res. 2020, 35, 4794-4797. [CrossRef]

29. Barla, A.; Ozturk, M.; Kultur, S.; Oksuz, S. Screening of antioxidant activity of three Euphorbia species from Turkey. Fitoterapia 2007, 78, 423-425. [CrossRef]

30. Battu, G.R.; Ethadi, S.R.; Veda Priya, G.; Swathi Priya, K.; Chandrika, K.; Venkateswara Rao, A.; Reddy, S.O. Evaluation of antioxidant and anti-inflammatory activity of Euphorbia heyneana Spreng. Asian Pac. J. Trop. Biomed. 2011, 1, S191-S194. [CrossRef]

31. Ben Jannet, S.; Hymery, N.; Bourgou, S.; Jdey, A.; Lachaal, M.; Magne, C.; Ksouri, R. Antioxidant and selective anticancer activities of two Euphorbia species in human acute myeloid leukemia. Biomed. Pharm. 2017, 90, 375-385. [CrossRef]

32. Sharma, N.; Samarakoon, K.W.; Gyawali, R.; Park, Y.-H.; Lee, S.-J.; Oh, S.J.; Lee, T.-H.; Jeong, D.K. Evaluation of the antioxidant, anti-inflammatory, and anticancer activities of Euphorbia hirta ethanolic extract. Molecules 2014, 19, 14567-14581. [CrossRef]

33. Abdelhakim, S.; Rima, B.; Abdelouahab, B. Heavy Metals Chelating Ability and Antioxidant Activity of Phragmites australis Stems Extracts. J. Ecol. Eng. 2019, 20, 116-123. [CrossRef]

34. Zhou, J.; Yang, Q.; Zhu, X.; Lin, T.; Hao, D.; Xu, J. Antioxidant activities of Clerodendrum cyrtophyllum Turcz leaf extracts and their major components. PLoS ONE 2020, 15, e0234435. [CrossRef] [PubMed]

35. Hsieh, Y.J.; Chang, C.J.; Wan, C.F.; Chen, C.P.; Chiu, Y.H.; Leu, Y.L.; Peng, K.C. Euphorbia formosana root extract induces apoptosis by caspase-dependent cell death via Fas and mitochondrial pathway in THP-1 human leukemic cells. Molecules 2013, 18, 1949-1962. [CrossRef] [PubMed]

36. Munro, B.; Vuong, Q.V.; Chalmers, A.C.; Goldsmith, C.D.; Bowyer, M.C.; Scarlett, C.J. Phytochemical, Antioxidant and Anti-Cancer Properties of Euphorbia tirucalli Methanolic and Aqueous Extracts. Antioxidants 2015, 4, 647-661. [CrossRef]

37. Cheng, J.; Han, W.; Wang, Z.; Shao, Y.; Wang, Y.; Zhang, Y.; Li, Z.; Xu, X.; Zhang, Y. Hepatocellular Carcinoma Growth Is Inhibited by Euphorbia helioscopia L. Extract in Nude Mice Xenografts. Biomed. Res. Int. 2015, 2015, 601015. [CrossRef]

38. Al-Fatimi, M.; Friedrich, U.; Jenett-Siems, K. Cytotoxicity of plants used in traditional medicine in Yemen. Fitoterapia 2005, 76, 355-358. [CrossRef]

39. Magozwi, D.K.; Peter, X.; Langat, M.K.; Mhlanga, R.; Vukea, N.; Mare, J.-A.d.l.; Siwe-Noundou, X.; Krause, R.W.M.; Tembu, V.J. In vitro cytotoxic effects of chemical constituents of Euphorbia grandicornis Blanc against breast cancer cells. Sci. Afr. 2021, 14, e01002. [CrossRef]

40. Chen, T.; Stephens, P.A.; Middleton, F.K.; Curtin, N.J. Targeting the S and G2 checkpoint to treat cancer. Drug Discov. Today 2012, 17, 194-202. [CrossRef]

41. Hanahan, D.; Weinberg, R.A. Hallmarks of cancer: The next generation. Cell 2011, 144, 646-674. [CrossRef]

42. Kale, J.; Osterlund, E.J.; Andrews, D.W. BCL-2 family proteins: Changing partners in the dance towards death. Cell Death Differ. 2018, 25, 65-80. [CrossRef]

43. Porter, A.G.; Jänicke, R.U. Emerging roles of caspase-3 in apoptosis. Cell Death Differ. 1999, 6, 99-104. [CrossRef]

44. Kwan, Y.P.; Saito, T.; Ibrahim, D.; Al-Hassan, F.M.; Ein Oon, C.; Chen, Y.; Jothy, S.L.; Kanwar, J.R.; Sasidharan, S. Evaluation of the cytotoxicity, cell-cycle arrest, and apoptotic induction by Euphorbia hirta in MCF-7 breast cancer cells. Pharm. Biol. 2016, 54, 1223-1236. [CrossRef] [PubMed]

45. Shekofteh, N.; Ghafourian Boroujerdnia, M.; Khosravi, N.; Kalantar, K.; Malek-Hosseini, S.; Namdari, H.; Amirghofran, Z. Apoptosis-inducing Effect of the Hexane Extracts from Three Native Iranian Euphorbia Plants. Int. J. Cancer Manag. 2017, 10, e8306. [CrossRef]

46. Tiwari, P.; Kaur, M.; Kaur, H. Phytochemical screening and Extraction: A Review. Int. Pharm. Sci. 2011, 1,98-116.

47. Adebayo, S.A.; Shai, L.J.; Eloff, J.N. First isolation of glutinol and a bioactive fraction with good anti-inflammatory activity from n-hexane fraction of Peltophorum africanum leaf. Asian Pac. J. Trop. Med. 2017, 10, 42-46. [CrossRef] 
48. Jung, M.J.; Heo, S.I.; Wang, M.H. Free radical scavenging and total phenolic contents from methanolic extracts of Ulmus davidiana. Food Chem. 2008, 108, 482-487. [CrossRef]

49. Fukunaga, T.; Nishiya, K.; Kajikawa, I.; Watanabe, Y.; Suzuki, N.; Takeya, K.; Itokawa, H. Chemical Studies on the Constituents of Hyphear tanakae HOSOKAWA from Different Host Trees. Chem. Pharm. Bull. 1988, 36, 1180-1184. [CrossRef]

50. Nicollier, G.; Thompson, A.C. Flavonoids of Desmanthus illinoensis. J. Nat. Prod. 1983, 46, 112-117. [CrossRef]

51. Kirby, A.J.; Schmidt, R.J. The antioxidant activity of Chinese herbs for eczema and of placebo herbs-I. J. Ethnopharmacol. 1997, 56, 103-108. [CrossRef]

52. Singh, N.; Rajini, P.S. Free radical scavenging activity of an aqueous extract of potato peel. Food Chem. 2004, 85, 611-616 [CrossRef]

53. Nasr, F.A.; Shahat, A.A.; Alqahtani, A.S.; Ahmed, M.Z.; Qamar, W.; Al-Mishari, A.A.; Almoqbil, A.N. Centaurea bruguierana inhibits cell proliferation, causes cell cycle arrest, and induces apoptosis in human MCF-7 breast carcinoma cells. Mol. Biol. Rep. 2020, 47, 6043-6051. [CrossRef]

54. Alqahtani, A.S.; Nasr, F.A.; Noman, O.M.; Farooq, M.; Alhawassi, T.; Qamar, W.; El-Gamal, A. Cytotoxic Evaluation and Anti-Angiogenic Effects of Two Furano-Sesquiterpenoids from Commiphora myrrh Resin. Molecules 2020, 25, 1318. [CrossRef] 